\title{
O AMOR DE DOM PEDRO
}

Um homem, uma mulher, a paixão e uma insensata desforra são os personagens desta hislória. O cándido leilo do rio Mondego, que atravessa Coimbra, foi seu cenário. O tempo, que enquanto conceito é essencial para a ocorrência, é de pouca imporlância enquanlo medida cronológica: por dever da crônica direi que eslávamos, de qualquer maneira, em meados do décimo quarto século.

O antecedente dá parte do banal. Banais eram, então, os casa.nentos ditados por conveniências diplomáticas e por motivos de alianças. Banal era o jovem príncipe Dom Pedro que aguardava em seu palácio a prometida, uma fidalga da vizinha Espanha. E banalmente, como ditavam costume e normas, chegou a embaixatura nupcial: a fulura esposa, seus guardas, suas damas de honra. Ousaria dizer que banal foi ainda o príncipe ser tomado de amor por uma dama do séquito, a meiga Inês de Castro, que os cronistas e os poetas coevos, com os estilemas da época, descrevem do delgado pescoço e das róseas faces: banal porque, se era comum para um reinante desposar não uma mulher e sim uma razão de estado, igualmente comum era o satisfazer seus sentidos de homem com uma mulher em cuja direção fosse impelido por outros motivos que não os da conveniếncia política.

Mas o jovem Dom Pedro alentava o sentimento de uma imprescindível monogamia, este é o primeiro clemento nāo banal da ocorrência. Afervorado por um amor único e indivisível pela meiga Inês, Dom Pedro transgrediu os sutis cânones do sub-reptício e as cautelas da diplomacia. O casamento fora-lhe imposto por motivos estritamente dinásticos, e ele os cumpriu de um ponto de vista estritamente dinástico: uma vez tido o herdeiro que a vontade do velho pai exigia, acomodou-se com Inês num castelo sobre o Mondego e fez dela, sem casamento, sua verdadeira esposa. É o segundo elemento não banal da história. A esta allura, na figura de um impassível algoz, entra em cena a fria violência da razão. $O$ velho rei era um homem sábio e prudente, e amava no filho, mais do que o filho, o rei que ele seria. Reuniu os conselheiros do reino e estes sugeriram um remédio que lhes pareceu definitivo: apagar da realidade o obstáculo ao bom senso do Estado. Durante uma ausência do príncipe, Dona Inês foi passada à espada, como relata um cronista, em sua morada de Coimbra.

Passaram-se os anos. A rainha legítima já havia morrido, há tempo. Depois, um dia, o velho pai também morreu, e Dom Pedro tornou-se rei. Sua vingança começa a esta altura. De início foi uma vingança cruel e nefanda, mas que ainda pertence à lógica das ações humanas. Com prodigiosa paciên- 
Textos extrafdus de I volatlli del Beato Angelko, Palermo, Sellerio, 1987. $O$ amor de Dom Pedro.

cia e meticulosidade de tabelião cle fez com que sua polícia encontrasse os antigos conselheiros paternos. Alguns, já velhos e destituídos de suas incumbências, viviam em tranqüilo retiro; outros foi difícil alcançar: plausíveis receios os haviam conduzido fora de Porlugal, onde prestavam seus serviços a outros monarcas. Dom Pedro aguardou-os, um por um, no pátio de seu palácio. Perseguia-o a insônia. Certas noites levantava-se e rompia o insuportável silêncio de seus aposentos, mandava acender todas as tochas, chamava os trombeteiros e ordenava que tocassem. $O$ cronista da época que anota os eventos é pródigo em detalhes: descreve o pátio austero e despojado, o reboar dos cascos dos cavalos sobre as pedras, o retinir dos ferrolhos, o grito dos guardas que anunciavam a captura de um procurado. Descreve também a pacienle espera de Dom Pedro, imóvel a uma janela pela qual dominava o átrio e o caminho por onde chegariam suas vítimas. Ele era um homem alto e muito magro, com um rosto ascético e uma longa barba em ponta, como um barbeiro-cirurgião ou um sacerdote, e sempre vestia um idêntico manto sobre um idêntico gibão. O preciso cronista relata da mesma forma os diálogos, antes as súplicas, que os prisioneiros dirigiam a seu algoz, e que jamais tiveram resposta: o rei limitava-se a fornecer relaçóes de natureza técnica sobre o modo que considerava mais idôneo para pôr fim à vida de suas vítimas. Dom Pedro não era homem desprovido de ironia: para um prisioneiro de nome Coelho, escolheu por exemplo uma morte na grelha. Mandava, em todo o caso, que o peito de todos fosse dilacerado, o de alguns quando ainda em vida, e mandava extirpar o coração que lhe era entregue numa bandeja de cobre. Ele pegava o órgão ainda quente e jogava-o à sua matilha de cães que esperavam, ávidos, sob o terraço.

Mas sua vingança sanguinária, que deixa horripilado o bom cronista, foi para Dom Pedro um placebo de escassa eficácia. Seu ressentimento de homem arrastado por eventos irremediáveis não se contentou com o músculo cardiáco de alguns cortesāos: na solidão empedernida de seu palácio ele meditou uma desforra mais sutil, que não concerne o plano do pragma e do humano, e sim o do Tempo e do encadeamento dos eventos que são a vida e que naquele caso já haviam sido. Ele pensou corrigir o definitivo.

Era um quente verão de Coimbra, e rente ao leito do rio cresciam lavanda e giestas. As lavadeiras batiam suas roupas no ribeiro preguiçoso que corria como uma serpente em meio aos seixos rolados; e cantavam. Dom Pedro compreendeu que tudo - seus súditos, aquele rio, as flores, os cantos, e até ele próprio, rei que olhava seu reino - teria sido idéntico mesmo que tudo tivesse sido diferente e nada houvesse ocorrido; e que a formidável plausibilidade da existência, inexorável como é inexorável o que é real, era mais maciça do que sua ferócia, era inexpugnável por sua vingança. $O$ que 
R. Itallanístlca, São Paulo, ano II, n"2 2, p. 173-175, 1994.

pensou exatamente, enquanto olhava por sua jancla as louras planícies de Portugal? Que tipo de pena o assolou? A saudade do que foi, pode consumir; mas a do que desejaríamos que tivesse sido, deve ser intolerável. Provavelmente Dom Pedro foi arrastado por esta saudade. Em sua incurável insônia, a cada noite, ele olhava as estrelas: e talvez as distâncias siderais, os espaços incomensuráveis pelo tempo humano deram-lhe a inspiração. Talvez para tal inspiração concorreu também a ironia sutil que, com a saudade do que não fora, se agasalhava em seu peito. Ele meditou um plano genial.

Dom Pedro, como se viu, era homem tacanho de palavras e de firme caráter: no dia seguinte uma proclamação frugal anunciava por todo o reino uma grande festa do povo, a coroação de uma rainha, uma solene viagem de núpcias, entre duas alas de multidão exultante, de Coi nbra a Alcobaça. Dona Inês foi exumada da sepultura. O cronisıa não revela se já era um esqueleto desnudo ou estava diversamente decomposta. Foi vestida de branco, c. vroada e colocada sobre o coche real aberto, à direita do rei. Puxava a carruagem uma parelha de cavalos brancos, com grandes penachos coloridos. Guizeiras de prata nos focinhos dos animais irradiavam, a cada passo, um som retininte. A multidão, como fora ordenado, fez ala ao cortejo nupcial, conjugando reverência de súdilos e repugnância. Estou propenso a crer que Dom Pedro, despreocupado com as aparências, das quais o defendiam, afinal, os poderes de uma poderosa imaginação, leve a certeza de viajar não com o cadáver de sua antiga amada, e sim com ela, real, antes de ser morta. Poderia se sustentar que ele fosse essencialmente louco, mas seria uma evidente simplificação.

De Coimbra a Alcobaça correm oitenta quilômetros. Dom Pedro vollou sozinho, incógnito, de sua imaginária lua-de-mel: à espera de Dona Inês, na abadia de Alcobaça, havia uma morada de pedra cuja escultura o rei encomendara a um renomado artista. Diante do sarcófago de Inês, reproduzida que estava sobre a tampa em sua beleza juvenil, pés contra pés, de forma que no dia do juízo seus moradores se encontrassem rosto a rosto, havia um sarcófago análogo, com a imagem do rei.

Dom Pedro teve que esperar muitos anos ainda, antes de tomar lugar no sarcófago a ele reservado. Utilizou este tempo para desempenhar seu ofício de rei: cunhou moedas de ouro e de prala, pacificou seu reino, escolheu uma mulher que levasse ledice a seus aposentos; foi um pai exemplar, um companheiro discreto e cortês, um límpido administrador da justiça. Conheceu até mesmo a alegria, e deu algumas festas. Mas estes me parecem detalhes irrelevantes. Aqueles anos, provavelmente, tiveram para ele uma dimensāo diferente da dimensão de qualquer homem. Foram todos iguais, e talvez todos imedialos, como se já tivessem decorrido. [RB] 